\title{
UJI AKTIVITAS ANTIHIPERURISEMIA EKSTRAK ETANOL BIJI SALAK (Salacca zalacca (Gaertn.) Voss.) TERHADAP TIKUS PUTIH JANTAN GALUR WISTAR (Rattus norvegicus) YANG DIINDUKSI KALIUM OKSONAT
}

\author{
Lia Krisdayanti, Hajrah, Adam M. Ramadhan \\ Laboratorium Penelitian dan Pengembangan FARMAKA TROPIS \\ Fakultas Farmasi Universitas Mulawarman, Samarinda, Kalimantan Timur \\ *email: liakrisdayanti96@yahoo.com
}

\begin{abstract}
ABSTRAK
Pada penelitian sebelumnya dinyatakan bahwa ekstrak etanol biji salak memiliki aktivitas sebagai diuretik, dan dinyatakan bahwa senyawa yang berperan adalah flavonoid. Senyawa flavonoid diduga memiliki aktivitas dalam penurunan kadar asam urat. Penelitian ini bertujuan untuk mengetahui aktivitas pemberian ekstrak etanol biji salak (Salacca zalacca (Gaertn) Voss), mencari dosis terbaik dan mengetahui potensinya dalam menurunkan kadar asam urat pada tikus putih jantan galur wistar (Rattus norvegicus). Metode yang digunakan adalah secara in vivo dengan menggunakan hewan uji tikus putih jantan galur wistar (Rattus norvegicus) yang diinduksi kalium oksonat dan jus hati ayam. Tikus dibagi ke dalam 4 kelompok, yaitu kelompok kontrol negatif (Na-CMC 0,5\%), ekstrak dosis $70 \mathrm{mg} / \mathrm{kgBB}$, ekstrak dosis $140 \mathrm{mg} / \mathrm{kgBB}$ dan ekstrak dosis $280 \mathrm{mg} / \mathrm{kgBB}$. Setiap kelompok terdiri dari 3 tikus. Dilakukan pemberian jus hati ayam 1 jam setelah induksi kalium oksonat lalu kadar asam urat diukur 60 menit dan 120 menit; setelah induksi. Kadar asam urat tikus diukur dengan menggunakan alat test-strip asam urat. Hasil yang diperoleh menujukkan bahwa ekstrak etanol biji salak (Salacca zalacca (Gaertn) Voss) memiliki aktivitas dalam menurunkan kadar asam urat tikus putih jantan galur wistar (Rattus norvegicus).
\end{abstract}

Kata Kunci : hiperurisemia, kalium oksonat, jus hati ayam, ekstrak etanol biji salak

\begin{abstract}
In a previous study revealed that the ethanol extract of salak seeds has activity as a diuretic, and it is stated that compounds that act is flavonoids. Flavonoid compounds suspected to have activity in reducing uric acid levels. The aim of this study was to know the effect of administration, to look for the best dose and to know the potency of ethanol extract of salak seeds (Salacca zalacca (Gaertn) Voss) in decreasing uric acid levels of Wistar white male mice (Rattus norvegicus). The method was in vivo anti-hyperuricemia activity using potassium oxonate and induced hyperuricemia mice and chicken liver juice. The mice were

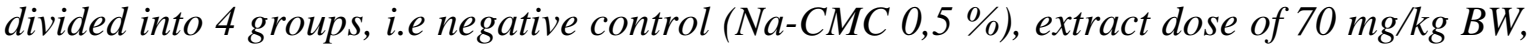
extract dose of $140 \mathrm{mg} / \mathrm{kg} \mathrm{BW}$ and extract dose of $280 \mathrm{mg} / \mathrm{kg} \mathrm{BW}$. Each group consisted of 3 mice. The chicken liver juice were given orally at 1 hour after induction potassium oxonate and uric acid levels were measured 60 minutes and 120 minutes; after induction.The uric acid levels were measured by using a test-strip gout. The results obtained showed that the ethanol extract of salak seeds (Salacca zalacca (Gaertn) Voss) has activity in decreasing uric acid levels of Wistar white male mice (Rattus norvegicus).
\end{abstract}

Keywords : hyperuricemia, potassium oxonate, chicken liver juice, ethanol extract of salak seeds 


\section{PENDAHULUAN}

Hiperurisemia adalah keadaan dimana kadar asam urat di dalam darah meningkat dan mengalami kejenuhan. Hal ini dapat terjadi karena meningkatnya sintesis asam urat tersebut, penurunan ekskresi asam urat oleh ginjal atau keduanya. Kadar normal asam urat dalam darah adalah 3,4-7,0 mg/dL pada pria dan 2,4-5,7 mg/dL pada wanita (Hardian, 2014)

Hiperurisemia dapat diatasi dengan menurunkan produksi asam urat. Allopurinol sebagai inhibitor spesifik dari enzim xanthin oksidase (XO) yang mengkatalisis oksidasi hipoxanthin menjadi xanthin dan asam urat, terbukti efektif dalam menurunkan kadar asam urat (Ni putu, 2012). Akan tetapi, terapi dengan menggunakan allopurinol mempunyai beberapa efek samping yang berbahaya seperti eksim, dapat terjadi reaksi hipersensitivitas pada hati, dapat menyebabkan gagal hati, hepatitis, hiperbilirubinemia dan jaundice, dapat menyebabkan diare, konstipasi, muntah dan mual (Salsabila, 2015). Oleh karena itu perlu dikembangkan obat-obatan tradisional sebagai antihiperurisemia. Salah satu bahan alam yang berpotensi untuk dimanfaatkan sebagai antihiperurisemia adalah salak.

Herliani (2011), menyatakan bahwa ekstrak etil asetat buah salak varietas bongkok (Salacca edulis Reinw) berfungsi sebagai antihiperurisemia karena dapat menghambat aktivitas enzim xantin oksidase pada tikus galur wistar dan ekstrak etanolnya sebagai urikostatik dan urikosurik. Novita (2014), menyatakan bahwa ekstrak etanol biji salak (Salacca zalacca varietas zalacca (gaert.) Voss) memiliki efek diuretik terhadap tikus putih jantan galur wistar (Rattus norvegicus), adapun senyawa yang berperan dalam meningkatkan volume urin adalah senyawa flavonoid. Menurut Afrianti (2011), senyawa antioksidan alami tumbuhan umumnya adalah golongan flavonoid. Flavonoid merupakan salah satu golongan senyawa aromatik alam. Beberapa flavonoid dari suatu tanaman dapat mengendalikan kenaikan kadar asam urat plasma tikus percobaan dengan mencegah pembentukan radikal bebas. Berdasarkan kandungan metabolit sekunder dan pendekatan genus, diduga biji salak mampu menurunkan kadar asam urat di dalam darah sehingga perlu dilakukan pengujian aktivitas antihiperurisemia ekstrak etanol biji salak pada tikus.

\section{METODOLOGI PENELITIAN}

\section{Bahan dan Alat}

Bahan yang digunakan adalah biji salak, kertas saring, aluminium foil, alkohol 70\%, kapas, aquades, natrium karboksil metilselulosa (Na-CMC), etanol, silica gel, tikus, kalium oksonat dan alopurinol. Alat yang digunakan antara lain timbangan analitik Precisa®XB 220 A, wadah maserasi, rotary evaporator Buchi IKA® HB 10 Basic, hot plate-stirrer Stuart $\circledast$ $C B 162$, mortir dan stemper, spoit, sonde oral, holder, gunting bedah, dan alat test strip asam urat $\mathrm{Nesco®}$.

\section{Pembuatan Simplisia}

Biji salak dibersihkan dan dicuci bersih dengan air mengalir, ditiriskan kemudian ditumbuk kecil-kecil lalu diblender, selanjutnya dikeringkan dengan cara diangin-anginkan. Setelah kering, sampel disortasi ulang.

\section{Pembuatan Ekstrak Etanol Biji Salak}

Pembuatan ekstrak etanol biji salak dilakukan dengan metode maserasi. Biji salak kering dimasukkan ke dalam toples kemudian ditambahkan pelarut etanol dan dimaserasi selama 2 x 24 jam. Ekstrak kemudian disaring dengan kertas saring dan dilakukan remaserasi dengan pelarut etanol. Ekstrak biji salak dipekatkan dengan menggunakan rotary evaporator pada tekanan $55 \mathrm{cmhg}$ dan suhu $50^{\circ} \mathrm{C}$. Ekstrak kental dikeringkan dengan cara dianginanginkan. 


\section{Pembuatan Suspensi NaCMC 0,5\%}

Sebanyak 0,5 gram NaCMC ditaburkan ke dalam mortir yang berisi $10 \mathrm{~mL}$ aquades panas dan didiamkan selama 15 menit hingga diperoleh massa yang transparan, kemudian digerus sampai homogen. Selanjutnya diencerkan dengan aquades dan dimasukkan ke dalam labu ukur $100 \mathrm{~mL}$. Volume dicukupkan sampai tanda batas.

\section{Pembuatan Kalium Oksonat}

Ditimbang kalium oksonat sesuai dengan perhitungan $(50 \mathrm{mg} / 200 \mathrm{gBB}$ tikus). Digerus kalium oksonat dan ditambahkan suspensi $\mathrm{Na}$ CMC 0,5\% yang telah dikembangkan dalam air panas sebanyak 20 kalinya dan digerus homogen. Ditambahkan $\mathrm{NaCl}$ fisiologi sampai $5 \mathrm{~mL}$.

\section{Penyiapan Suspensi Jus Hati Ayam}

Disiapkan hati ayam 5 gram. Diblender hati ayam dengan menggunakan air sebanyak $50 \mathrm{~mL}$. Dimasukkan kedalam wadah.

\section{Penyiapan Dosis Allopurinol}

Dilakukan timbang setara dengan cara ditimbang 20 tablet allopurinol. Dilakukan penimbangan allopurinol sesuai dengan perhitungan (dosis manusia : $200 \mathrm{mg} / \mathrm{hari}$.). Digerus allopurinol dan ditambahkan suspensi $\mathrm{Na} \mathrm{CMC} 0,5 \%$ yang telah dikembangkan dalam air panas sebanyak 20 kalinya dan digerus homogen. Ditambahkan suspensi Na CMC 0,5\% hingga tanda batas.

\section{Pembuatan Suspensi Ekstrak Etanol Biji Salak}

Variasi dosis yang digunakan yaitu ekstrak daun sepat dosis $70 \mathrm{mg} / \mathrm{kg} \mathrm{bb}, 140 \mathrm{mg} / \mathrm{kg}$ bb, dan $280 \mathrm{mg} / \mathrm{kg}$ bb. Setiap dosis ekstrak etanol biji salak yang digunakan dilarutkan dalam suspensi NaCMC 0,5\% kemudian dicukupkan volume suspensi dalam labu ukur $5 \mathrm{~mL}$ hingga tanda batas. Volume pemberian dihitung berdasarkan berat badan dan diberikan secara per oral.

\section{Pengujian Aktivitas Antihiperurisemia}

Hewan uji yaitu tikus jantan yang dikelompokkan dalam 4 kelompok. Semua hewan uji dipuasakan selama 12 jam (tetap diberi minum). Semua hewan uji yang telah dipuasakan ditimbang berat badannya kemudian diukur kadar asam urat awal. Dilakukan pemberian kalium oksonat secara intraperitoneal. Dioralkan jus hati ayam setelah 1 jam induksi. Dilakukan pengukuran kadar asam urat setelah 1 jam penginduksian dengan menggunakan alat strip asam urat. Dilakukan perlakuan sesuai kelompok. Pemberian suspensi Na-CMC untuk kontrol negatif, dan pemberian larutan ekstrak untuk kelompok uji. Di ukur kadar asam urat setiap jam selama 3 jam.

\section{Analisis Data}

Data yang diperoleh dianalisis secara deskriptif dengan membandingkan selisih penurunan kadar asam urat darah tikus.

\section{HASIL DAN PEMBAHASAN}

Hiperurisemia adalah kondisi kadar asam urat di dalam darah meningkat dan mengalami kejenuhan yang dapat terjadi karena meningkatnya sintesis asam urat, penurunan ekskresi asam urat oleh ginjal atau keduanya. Tujuan dilakukannya penelitian ini adalah untuk mengetahui pengaruh pemberian ekstrak etanol biji salak (Salacca zalacca (Gaertn) 
Voss), mencari dosis terbaik dan mengetahui potensinya dalam menurunkan kadar asam urat pada tikus putih jantan galur wistar (Rattus norvegicus).

Penelitian ini terdiri atas 4 kelompok yang terbagi atas kelompok kontrol negatif dengan pemberian suspensi NaCMC 0,5\%, kelompok uji dengan dosis ekstrak etanol biji salak $70 \mathrm{mg} / \mathrm{kg}$ bb, kelompok uji dengan dosis etanol biji salak $140 \mathrm{mg} / \mathrm{kg}$ bb, dan kelompok uji dengan dosis ekstrak etanol biji salak $280 \mathrm{mg} / \mathrm{kg}$ bb. Pengukuran kadar asam urat darah dilakukan sebanyak 4 kali yaitu kadar asam urat darah sebelum dan sesudah induksi kalium oksonat (t0 dan t1), serta kadar asam urat darah pada tikus pada jam ke-1 (t2), jam ke-2 (t3), setelah penginduksian hiperurisemia. Hasil pengukuran kadar asam urat tikus ditunjukkan pada Tabel 1.

Tabel 1. Hasil pengukuran kadar asam urat darah tikus

\begin{tabular}{cllll}
\hline & \multicolumn{4}{c}{ Kadar Asam Urat Darah (mg/dL) } \\
\cline { 2 - 5 } Dosis & $\begin{array}{c}\text { Kontrol } \\
\text { negatif }\end{array}$ & $\begin{array}{c}\text { Dosis 70 mg/kg } \\
\text { bb }\end{array}$ & $\begin{array}{c}\text { Dosis 140 } \\
\mathrm{mg} / \mathrm{kg} \mathrm{bb}\end{array}$ & $\begin{array}{c}\text { Dosis 280 } \\
\mathrm{mg} / \mathrm{kg} \mathrm{bb}\end{array}$ \\
\hline T0 & 3,57 & 3,00 & 3,00 & 3,10 \\
T1 & 7,10 & 14,87 & 9,23 & 8,03 \\
T2 & 4,23 & 6,93 & 4,73 & 6,33 \\
T3 & 4,53 & 4,63 & 3,67 & 5,83 \\
\hline Keterangan: & T0: sebelum induksi hiperurisemia & \\
& T1: setelah induksi hiperurisemia & \\
& (sebelum diberikan ekstrak) & \\
& T2: jam ke-1 setelah diberikan ekstrak & \\
& T3: jam ke-2 setelah diberikan ekstrak &
\end{tabular}

Tabel 1 menunjukkan hasil pengujian aktivitas antihiperurisemia ekstrak etanol biji salak. Kadar normal asam urat tikus adalah 1,7-3,0 mg/dL[7]. Hasil tersebut menunjukkan bahwa telah terjadi kondisi hiperurisemia pada t1 untuk semua kelompok hewan uji.

Kelompok kontrol negatif yang diberikan suspensi NaCMC 0,5\% kadar asam urat mencapai kadar tertinggi pada saat setelah pemberian induksi (t1) sebesar 7,10 mg/dL kemudian turun hingga 4,23 mg/dL pada (t2) dan mengalami kenaikan kembali sebesar 4,53 $\mathrm{mg} / \mathrm{dL}$ pada (t3). Kadar asam urat tikus pada kelompok uji dosis $70 \mathrm{mg} / \mathrm{kg}$ bb naik mencapai kadar tertinggi pada saat setelah pemberian induksi (t1) sebesar 14,87 mg/dL, kemudian turun turun hingga $6,93 \mathrm{mg} / \mathrm{dL}$ pada (t2) dan mengalami penurunan kembali sebesar 4,63 $\mathrm{mg} / \mathrm{dL}$ pada (t3). Kadar asam urat tikus pada kelompok uji dosis $140 \mathrm{mg} / \mathrm{kg}$ bb naik mencapai kadar tertinggi pada saat setelah pemberian induksi (t1) sebesar 9,23 mg/dL, kemudian turun hingga 4,73 mg/dL pada (t2) dan mengalami penurunan kembali sebesar $3,67 \mathrm{mg} / \mathrm{dL}$ pada (t3). Kadar asam urat tikus pada kelompok uji dosis $280 \mathrm{mg} / \mathrm{kg}$ bb naik mencapai kadar tertinggi pada saat setelah pemberian induksi (t1) sebesar 8,03 mg/dL, kemudian turun hingga $6,33 \mathrm{mg} / \mathrm{dL}$ pada (t2) dan mengalami penurunan kembali sebesar $5,83 \mathrm{mg} / \mathrm{dL}$ pada (t3). Rata-rata kenaikan dan penurunan kadar asam urat serta aktivitas antihiperurisemia ekstrak etanol biji salak dapat dilihat pada grafik berikut. 


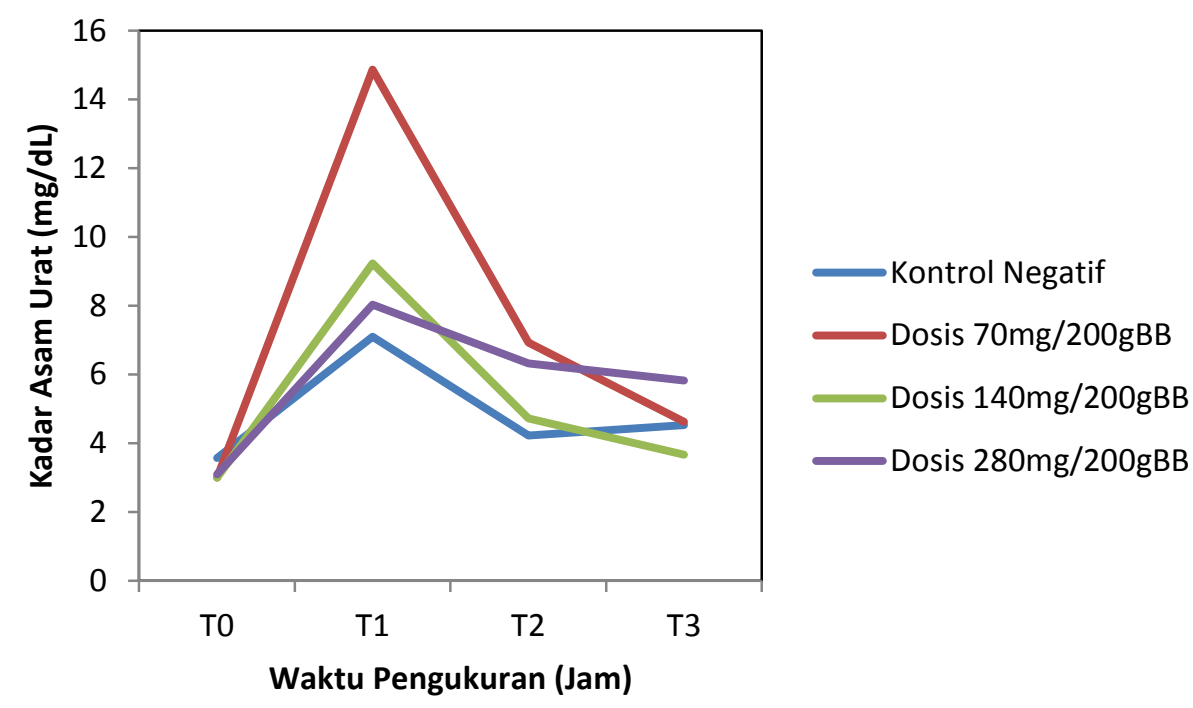

Gambar 1. Grafik kadar asam urat darah tikus

Berdasarkan grafik rata-rata kadar asam urat tikus diatas, dapat dilihat bahwa terdapat perbedaan penurunan kadar asam urat darah pada kelompok negatif, kelompok uji dosis ekstrak $70 \mathrm{mg} / 200 \mathrm{gBB}$, dosis $140 \mathrm{mg} / 200 \mathrm{gBB}$, dan dosis $280 \mathrm{mg} / 200 \mathrm{gBB}$. Data yang diperoleh kemudian dianalisis dengan metode analisis deskriptif dengan melihat jumlah penurunan kadar asam urat darah tikus pada jam ke-1 (t2) sampai jam ke-2 (t3).

Pada grafik diatas dapat dilihat bahwa terjadi kenaikan pada semua kelompok pada waktu t1, hal ini dikarenakan adanya penginduksian kalium oksonat dan jus hati ayam sebagai bahan penginduksi hiperurisemia. Kalium oksonat disini digunakan sebagai merupakan inhibitor urikase, yang mana enzim urikase sendiri adalah enzim yang mengkatalisis perubahan asam urat menjadi alantoin yang sifatnya lebih larut dalam air (dapat diekskresikan lewat urin) sehingga dipakai sebagai bahan penginduksi pada model

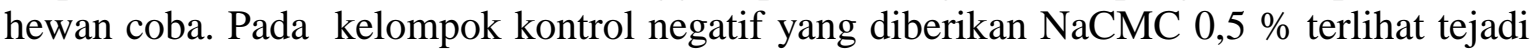
penurunan pada $\mathrm{t} 2$, hal ini dapat dikarenakan adanya aktivitas dari enzim urikase yang mana menyebabkan asam urat berubah menjadi allantoin yang bersifat mudah untuk diekskresikan hal ini dapat terjadi akibat penyerapan kalium oksonat yang kurang maksimal. Setelah itu terjadi kenaikan kadar kembali pada $\mathrm{t} 3$, hal ini dapat dikarenakan terjadinya pembentukan kembali asam urat pada hewan coba. Pada kelompok uji dosis ekstrak $70 \mathrm{mg} / 200 \mathrm{gBB}$; dosis $140 \mathrm{mg} / 200 \mathrm{gBB}$; dosis $280 \mathrm{mg} / 200 \mathrm{gBB}$ kadar asam urat darah puncak terjadi pada t1, yakni kadar setelah pemberian induksi hiperurisemia dan mengalami penurunan pada 2 , yakni satu jam setelah perlakuan yang mana sesuai dengan kelompok masing-masing. Hal ini dapat disebabkan oleh senyawa antioksidan seperti flavonoid yang terkandung di dalam biji salak. Menurut Afrianti (2011) beberapa flavonoid dari suatu tanaman dapat mengendalikan kenaikan kadar asam urat tikus dengan mencegah pembentukan radikal bebas. Berdasarkan dari hasil pengujian diatas dan analisis deskriptif, maka dapat dikatakan bahwa pada kelompok uji dosis ekstrak $70 \mathrm{mg} / 200 \mathrm{gBB}$; dosis $140 \mathrm{mg} / 200 \mathrm{gBB}$; dosis $280 \mathrm{mg} / 200 \mathrm{gBB}$ terjadi penurunan kadar asam urat pada jam ke-1 dan jam ke-2 setelah pemberian induksi hiperurisemia. Hal ini menunjukkan bahwa ekstrak etanol biji salak (Salacca zalacca (Gaertn) Voss) memiliki aktivitas dalam menurunkan kadar asam urat darah tikus putih jantan galur wistar (Rattus norvegicus.) 


\section{PENUTUP}

\section{Kesimpulan}

Berdasarkan hasil penelitian yang telah dilakukan maka dapat disimpulkan bahwa ekstrak etanol biji salak memiliki aktivitas dalam menurunkan kadar asam urat darah.

\section{Saran}

Perlu dilakukan pengujian lebih lanjut untuk menguji aktivitas etanol biji salak dengan metode yang berbeda serta dilakukan pengujian lebih lanjut untuk mengisolasi senyawa yang memiliki aktivitas dalam menurunkan kadar asam urat darah dalam ekstrak etanol biji salak.

\section{DAFTAR PUSTAKA}

Afianti, H. 2011. Aktivitas Antihiperurisemia Ekstrak Etil Asetat Dan Etanol Buah Salak Varietas Bongkok (Salacca edulis Reinw.) Pada Tikus Wistar. Jurnal Teknologi dan Industri Pangan. Vol XXII No. 1

Hardian et al. 2014. Aktivitas Antihiperurisemia Ekstrak Etanol Daun Lada (Piper nigrum L.) Pada Mencit (Mus musculus L.)Jurnal Trop. Pharm.Chem Vol. 2 No. 5

Herliani et al. 2011. Aktivitas Antihiperurisemia Ekstrak Etil Asetat Dan Etanol Buah Salak Varietas Bongkok (Salacca edulis Reinw.) Pada Tikus Galur Wistar. Jurnal Tekno Dan Industri Pangan. Vo. 22 No. 1.

Ni Putu et al. 2012. Ekstrak daun sirsak (Annona muricata L.) Sebagai antioksidan pada penurunan kadar asam urat tikus wistar. Jurnal Kimia. Vol. 6. No. 2

Novita et al. 2014. Uji efektivitas diuretik ekstrak etanol biji salak (salacca zalacca varietas zalacca (gaert.) Voss) pada tikus putih jantan galur wistar (Rattus norvegicus). Pharmacon. Vol. 3. No. 3

Salsabila et al. 2015. Uji Aktivitas Antihiperurisemia Ekstrak Etanol Kulit Buah Salak (Salacca zalacca (Gaertner) Voss) Terhadap Mencit Swiss Webster Jantan Yang Diinduksi Kalium Oksonat. Prosiding Penelitian SPeSIA Unisba

Windu A. Dewa. 2014. Pemanfaatan Teh Kombucha Sebagai Obat Hiperurisemia Melalui Penghambatan Aktifitas Zantin Oksidase Pada Rattus norvegicus. Jurnal Kimia No. 8 Vol. 2 